\title{
A normative approach to democracy in the electronic government framework
}

\author{
Andrea Maggipinto \\ C.I.R.S.F.I.D., University of Bologna \\ andrea.maggipinto@unibo.it \\ Ezio Visconti \\ Osservatorio "Centro Studi Informatica Giuridica" - Milan \\ osservatorio.mi@csig.it
}

\begin{abstract}
The process of modernization in the public administrations is considered to be the result of the implementation of computer science applications and digital technologies in the Public Administration (PA) for achieving institutional functions. The so called "electronic government" is one of the key objectives laid out in DG Information Society's i2010 Action plan, in which Europe aims to bring administrations closer to citizens, for example by providing on line public services. In this scenario of changing of means and goals, the electronic dialogue between agents - i.e. Public Administrations, citizens and enterprises - represents the key element for the development of the public sector. But e-government is neither a simple tool to provide better services in a better way by PA. to citizens nor a simple question of downsizing the administration (the back office) and up-sizing services (the front-office) i.e. a rebalancing from administration to services on a planned and sensible basis. Modern democracies are facing new challenges through the communication and information technology. The expression "electronic democracy" is characterized by the modality of citizens direct participation in the political life. In truth, this expression evokes wider and universal values.
\end{abstract}

\section{Introduction}

The process of modernization in the public administrations is often considered to be the result of the implementation of computer science applications and digital technologies in the Public Administration (PA) for achieving institutional functions, i.e. increasing the legitimacy, accountability and transparency of the decision-making process and involving them citizens directly in the policy process.

In particular, the European Community has recognized the importance of introducing technologies in public administrations to improve the organization, the effectiveness of the system and its transparency. In fact, the so called "electronic government" is one of the key objectives laid out in DG Information Society's i2010 Action plan [1], in which Europe aims to bring administrations closer to citizens, for example by providing on line public services. New digital technolo- 
gies, supporting transparency and participation, represent a way for good governance and to exercise civil and political rights.

Like in every sector of the social organization, the so called "public digital revolution" is based on what normally is called "Information and Communication Technology" (ICT), the technology for the elaboration and the transmission of electronic information.

\section{Framework: e-government and the electronic dialogue}

New instruments and objects have emerged from this technological scenario which arose for instance in Italy in a historical moment when the Italian Public Administration had just begun a process of organizational and procedural modernization with Laws nn. 142 and 241 in 1990. This technology impact is only relevant if it accomplishes the primary objective of the modernization process, namely simplification, transparency and social equality - into effect.

The "electronic government", or e-government, is a complex and multidimensional issue.

The European Commission defines it "as the use of information and communication technologies in public administrations combined with organisational change and new skills in order to improve public services and democratic processes and strenghthen support to public policies" [2].

The electronic government is not just ICTs: it also includes rules and procedures, because the public administration cannot innovate without a normative drive.

Electronic government also includes organization and processes. It starts with a deep analysis and a re-engineering of internal and external processes within an organization. Activities are subjected to a profound redesign and restructuring from a procedural, an organizational, and a regulative point of view. Processes, organization, rules and best practices are identified because they are considered sources of knowledge for e-government plan.

But electronic government also involves communication, interface methods and metaphors. For example, public services are planned and grouped in "life events", according to the flows of events in everyday life; the same goes for the enterprises. Moreover, multi-channel accesses should be guaranteed: the web, mobile phones, call centres, one-stop shops, earth digital television.

In this scenario of changing of means and goals, the electronic dialogue between agents - i.e. Public Administrations (PPAA), citizens and enterprises represents the key element for the development of the public sector. This interactive communication - not a mere unidirectional flow of information from Institutions to the citizen through often over informative websites - is able to carry out a sharing of information and knowledge that is both an instrument and the main task for the public administrations in the relationship with the citizens. 


\section{European action plan}

As the use of ICT grows, so does its impact on society, also in the relationships between Institutions and citizens.

E-government is expected to improve and accelerate administrative efficiency in order to reach the EU's Lisbon targets of sustainable economic growth and competitiveness. The Commission is encouraging member states' actions by financing projects and securing the technical interoperability of e-government services across Europe.

In particular, the Member States have to achieve an Inclusive European Information Society, as we can see in the third priority of i2010 Action plan: "achieving an Inclusive European Information Society that promotes growth and jobs in a manner that is consistent with sustainable development and that prioritises better public services and quality of life".

"Electronic inclusion" aims to prevent the risks of digital exclusion, that is to ensure that disadvantaged people are not left behind and to avoid new forms of exclusion due to lack of digital literacy or of Internet access. At the same time einclusion also means tapping new digital opportunities for the inclusion of socially disadvantaged people and less-favoured areas. The Information Society has the potential to distribute more equally knowledge resources, to offer new job opportunities, also by overcoming the traditional barriers to mobility and geographic distance, and to make the Institutions closer to the citizens.

"Inclusive eGovernment" is the use of ICT to provide public services that enrich citizen's lives, stimulate public participation in the community, strengthen democracy and reach out to people at risk of social, economic or digital exclusion.

\section{Participation and transparency}

Internet represents a great instrument for sharing and meeting ideas, also political. That's the reason why is undeniable that the Network has a social function. So it has a direct effect also on the relationships between Citizens and Institutions.

Quite often the expression "electronic democracy" (or e-democracy) is characterized by the modality of citizens direct participation in the political life. In truth, this expression evokes wider and universal values.

It is not possible to define the unique model of democratic State. There are many reasons (above all, extra-legal) on which the choice towards a particular kind of state and system of government are made, and these reasons surely cannot be conditioned by the introduction of new technologies. The before mentioned instead facilitates the Institutions to more efficiently manage the procedures in which the State functions, also if these technological instruments are used by direct, deliberative or representative democracy. 
The governance of technological innovation represents a way to fuel the continuous renewal towards more efficient democratic models. The collaboration between citizens and Institutions is only a positive aspect if it's well planned and constructed. However, there are two reasons for which the instruments of direct participation do not represent the main aspect of the technological innovation in the digital era.

Firstly, in the so called "advance democracies" it seems clear that the recognition of individual rights lessens the citizens political involvement and their interest in Institutional activities. Whereas, in developing countries, where there's a lack of individual rights, there seems to be more political involvement from the citizens through direct participation mechanisms.

Secondly, the real obstacles of the direct citizen participation in the law making process and decision making should be considered. They are not surely technological, but organizational, cultural and also constitutional. So, before planning technological instruments for direct participation, it would be opportune to consider all the aspects and the questions related to the direct participation mechanisms.

The pluralistic theory underlines nowadays the crisis of the representative democracy, so maybe it would be logical that the associations and the interest groups should get more involved into political life.

The technological society shows the problem of the democratic society: the necessity to reduce the complexity of the problems, so these can be achieved by the democratic processes.

The interdependence of the social sectors makes worse the complexity of the political decisions. In this technical-scientific and highly organized society, there is the risk of the discrepancy between social needs and decisional competences.

It isn't by chance that in Italy mechanisms - like the public consultations - have been introduced to achieve the goal of involving the social organizations and to better satisfy the social needs.

In connection with the instruments of participation, it will be decisive the way in which in Italy the principle of the Article 9 of the D.Lgs. 82/2005 (the "Code of the Digital Administration") will be achieved: "The State favours every use of new technologies in order to promote a greater participation of the citizens, also living abroad, to the democratic process and in order to facilitate the exercise of the political and civil rights, both individual and general rights".

The participation of the citizens to the political life will be possible through mechanisms that involve the communities and the political groups, based on the principle of liberty and equality. These mechanisms of "structured participation" represent a big incentive for the promotion of the associations: the communities local or global ones - have today the possibility to create discussions and cooperation through the Internet.

This way of organized collaboration would be useful to mediate between individual interests and political power, a method for developing democracy and the 
e-government plans. The functional efficiency of the Institutions and the public administrations will depend on this mediations.

But transparency is also an important principle, one of the main elements of democracy, because describe the visibility of all institutions actions to the "world out there". It's the essential condition for the control of governments and parliaments; it's a "democratic imperative".

Each government process has to be made trackable and all documents, messages and work flow steps have to be made identifiable at the moment of querying itself and backwards to earlier moments.

Transparency of government indicates the willingness to take responsibility and provide legitimacy of all governmental actions to citizens and even pressure groups. The public value of transparency is the support it provides for the legitimacy of any given government, enabling criticism and proof of equal treatment before the law.

But openness therefore helps to ensure that the citizen, who, being made aware of both the internal functioning of the government and of the information on which decisions are based, is equipped to actively participate in the decision making process.

\section{Technologies and preconditions of democracy}

Modern democracies are facing new challenges through the communication and information technology.

First of all, the risk of divergence between universal constitutional principles and principles that regulate Governments action. The formal acknowledgment of individual rights does not assure a coherent exercise of the political and the administrative power. It is necessary to overcome the compromise determined by the social usefulness and political necessity. This compromise could make individual rights less effective.

In the "Information Society", equal conditions of access to the information must be guaranteed to put the equality principle into effect.

The governments have to write up preconditions on which the selfdetermination of the citizens is based, in order to avoid the otherwise unavoidable social divide (both generational and territorial).

The divide between rich and poor has also other deep roots, but we believe that the access to the information represents one of the conditions for the equality of the citizens in the free exercise of the political and civil rights.

The Public Institutions have the task of assuring intellectual formation of the citizens and the employees in computer science according to articles 8 and 13 of the Code of the Digital Administration. This intellectual formation is indispensable for the effective employment of new technologies in the relationships with Public Administration. The governments must assure an efficient scholastic sys- 
tem, to achieve an adequate level of knowledge of technologies that is necessary for the socialization and the intellectual and cultural formation of citizens.

But this formation is only useful in a scenario in which people are allowed to use technological instruments. In fact the so called "digital divide" represents the inequality of citizens both in their abilities to use new technologies and in the conditions of access to them.

In a recent opinion adopted by the Committee of the Regions [3], two kind of digital divide are stressed:

1. the first one is the "infrastructural digital divide", whereby the gap between those living in areas where advanced infrastructure and services are available and those living in areas with permanent geographical and natural handicaps where such infrastructure is lacking. This is a substantial barrier to the participation of all in the Information Society and to the possibility to follow innovative ways of interacting with Institutions and local administrations. The Committee calls it "a very real and substantial democratic deficit";

2. the second one is the "cultural digital divide", a gap in the knowledge needed to become a user of ICT Services between new and old Member States, between one Member State and another, between urban and rural areas and between the different generations and social classes that make up European society.

The Commission has made a communication [4] focused on the territorial divide regarding broadband access. It aims to make governments and institutions at all levels aware of the importance of this divide and of the concerns about the lack of adequate broadband services in the less developed areas of the Union. The Communication implements one of the priorities of the i2010 initiative - a European Initiative for growth and employment.

In the Communication, the Commission says: "Governments at all levels have recognised the impact that broadband may have on everyday lives and are committed to ensuring that its benefits are made available to all". And in particular on the e-government: "Broadband improves the capability of eGovernment services and allows a better interaction between governments, easing access to government for citizens and businesses. It facilitates the development of high-quality services and may increase organisational performance resulting in efficiency gains for the public administrations".

As new technologies have a strong impact on the social structure and create the conditions of its emancipation, the digital divide instead frustrates the any democratic development. In a technologically advanced society a "real citizenship" could be only if there are all the social and cultural preconditions.

Once these preconditions of democracy are created, the demand for electronic interaction and the ability of the PPAA to satisfy this demand will initiate a virtuous process that will carry the public sector to the complete innovation.

It's obvious that technologically neutral choices must be undertaken which mustn't lead to a specific "tecno-dependency". 
We believe technology is not an independent entity that produces social effects. In the analysis of the relationships between society and technology, it's therefore necessary to reconsider the thesis on the social changes caused by technology. The exact contrary is also true: the society influences the technology and it governs (or should govern) the technological progress in accordance with the social needs.

As already emerged in others fields (for example the protection of environment as a common good), the Government should make political choices keeping in mind the rights of the citizens of tomorrow, also in relation to the technological progress.

The rights of the future generations will also depend upon the choices that Countries make in the modernization process of public sector.

\section{Governance?}

E-government is neither a simple tool to provide better services in a better way by P.A. to citizens nor a simple question of down-sizing the administration (the back office) and up-sizing services (the front-office) - i.e. a rebalancing from administration to services on a planned and sensible basis.

Indeed according to Erkki Liikanen, member of the European Commission, it "should help to make democracy function better ... increasing democratic participation and involvement" [5].

To put briefly: E-government is a tool that promise to fulfill the conditions of good governance (not simply governance!), i.e "a method/mechanism for dealing with a broad range of problem/conflicts in which actors regularly arrive at mutually satisfactory and binding decisions by negotiating with each other and cooperating in the implementation of these decisions" [6], a method/mechanism having, as stated by the Commission of the European Communities [7], a set of five major characteristics, namely openness, participation, accountability, effectiveness and coherence.

Now, although there has been a god deal of thinking and writing about governance, the term remains largely descriptive rather than explanatory, ranging from a state-centric approach, in which government is the most important actor and steers society through authority (governance with government) to a network approach, stressing social systems autopoietic and self organizing structure (governance without government).

In between the two extremes of governance we find other more moderate approaches considering governance as a socio-political and linguistic process, such the so called "Duch School" where governance "is cooperative rather than adversarial, with policy outcomes resulting from overcoming the decisional and coordination problems inherent in large complex policy arena" [8].

It is not the aim of our paper to discuss deeply this huge amount of different conceptions of governance and the even more understandings of different modes of governance. We simply argue that any governance model is an idealised- 
normative model strangely oblivious of the contradictory tensions in which any form of governing is inevitably embedded [9].

What is missing in the governance literature are - let apart the very complicated question relating to the actual meaning of terms such state and civil society and their relationship, i.e. is ontological, epistemological and methodological value "the relations of domination or subordination within governance, between levels of governance and in the context of wider political-economic transformations" [9].

In other words and to conclude this short overview of the governance theme: what governance theorist fails to take into account is what Michel Foucault calls "governmentality", i.e the dramatic expansion in the scope of government, featuring an increase in the number and size of the governmental calculation mechanisms in order to produce the citizen best suited to fulfil governments' policies, through the elaboration and implementation of specific technologies of power (mentalities, rationalities, and techniques) aiming at governing subjects $[10,11]$.

In this perspective, democracy is not mainly elections, laws, and institutions but a society, a lived cultural experience, "not just out there in the public sphere," as Barbara Cruikshank [12] has put it, "but in here, at the very soul of subjectivity." Government is best conceived not as prime mover but as catalyst and resource of citizens, neither the problem nor the solution.

Democracy is, in fact, an "ideal form of life" (Karl Polanyi). It occurs in multiple sites, enlists multiple talents in addressing public problems, and results in multiple forms of strategic relationships of power and, at the same time, in strategies and conducts of common wealth. Resistance - positive resistance - is no longer merely reversal, but consists in a subject's becoming-autonomous within a structured set of institutions and practices through immanent critique.

Someone of you, we hope many, probably remember the famous dialogue between Alice and Humpty Dumpty in Lewis Carroll's famous novel, Through the Looking-Glass; a dialogue in which the two characters are discussing about semantic and pragmatic.

"When we use a word," Humpty Dumpty say, "it means just what we choose it to mean - neither more nor less". To this troublesome statement Alice objects the following: "The question is whether you can make words mean so many different things". And that is the answer by Humpty Dumpty: "The question is which is to be master - that's all".

Is the governance literature a form of humptydumptyan theory?

\section{References}

1. i2010 - A European Information Society for growth and employment. Communication from the Commission to the Council, the European Parliament, the European economic and social committee and the committee of the regions. Brussels, 1.06.2005 COM (2005) 229 final. 
2. The Role of eGovernment for Europe's Future. Communication from the Commission to the Council, the European Parliament, the European economic and social committee and the committee of the regions. Brussels, 26.9.2003 COM (2003) 567 final.

3. Opinion of the Committee of the Regions on Bridging the Broadband Gap and i2010 eGovernment Action Plan. 02.13.2007, 2007/C - 146/09.

4. Bridging the Broadband Gap. Communication from the Commission to the Council, the European Parliament, the European economic and social committee and the committee of the regions. Brussels, 20.3.2006, COM (2006) 129 final.

5. E. Liikanen, "e-Government and the European Union", speech at The Internet and the City Conference 'Local Government in the Information Society'. Barcelona, 21.3.2003. UPGRADE - The European Journal for the Informatics Professionals, vol. IV, no 2, April 2003, p. 7.

6. P.C. Schmitter, Participation in governance arrangements: is there any reason to expect it will achieve 'sustainable and innovative policies in a multi-level context'?, in J.R. Grote, B. Gbikpi (eds.) Participatory Governance. Political and Societal Implications, Opladen: Leske and Budrich, 2002, pp. 51-69.

7. Commission of the European Communities, European Governance. A white paper (COM 2001) 428 final, Brussels: CEC.

8. B.G. Peters, Governance: A Garbage Can Perspective, in Rehie Politikwissenschaft / Political Science Studies, Wien, 2002.

9. E. Swyngedouw, Let the People Govern? Civil Society, Governmentality and Governance-Beyond -the -State, available at www.ru.nl/socgeo/colloquium/humboldt.pdf

10. M. Foucault, Il faut défendre la société. Cours au Collège de France 1976, Paris: Gallimard/Seuil, 1997.

11. M. Foucault, The Subject and the Power, in H. Dreyfus, P. Rabinow, Michel Foucault: Beyond Structuralism and Hermeneutics, Brighton: Harvester, 1982.

12. B. Cruikshank, The Will to Empower: Democratic Citizens and other Subjects, Ithaca, N.Y., Cornell Un. Press, 1999. 